\title{
BIOCHEMICAL PATHWAYS OF METABOLIC DISORDERS IN PSORIASIS
}

\author{
O. V. Samburskaya (i) ${ }^{1,2}$, S. Yu. Kalinchenko (i) ${ }^{1,2}$, N. V. Batkaeva (i) ${ }^{1}$ \\ ${ }^{1}$ Institute of Medicine, Peoples' Friendship University of Russia \\ 6 Mikluho-Maklaya St., 117198 Moscow, Russia \\ 2 Professor Kalinchenko's Clinic \\ 4 Butyrskaya St., p. 2, 127015 Moscow, Russia
}

$\bowtie$ Samburskaya Olga — olga.samburskaya1429@yandex.ru

The development of metabolic disorders occurs in psoriasis: insulin resistance, systemic inflammation, atherosclerosis, oxidative stress and obesity. The paper presents pathological biochemical pathways of metabolic disorders development which is caused by common cytokine profile characteristic for psoriasis and obesity and they are tumor necrosis factor alpha (TNF- $\alpha$ ), interleukin- 6 (IL-6), and interleukin-8 (IL-8). The following links play a role in the development of insulin resistance: insulin receptor (IRS-1) and insulin receptor substrate (SIR-1), glucose transporter protein (GLUT-4), also there is a decrease in the phosphatidylinositol 3-kinase pathway (PI3AKT) activity, and an increase in the mitogen activating protein kinase (MAPK) activity. Factors influencing the development of inflammation are discussed: IL-6, C-reactive protein, tissue plasminogen activator inhibitor (PAI-1), monocyte chemoattractant protein 1 (MCP-1), proinflammatory adipokines; processes of vascular inflammation development, atherosclerosis development and oxidative stress. This article discusses endocrine disruption of adipocytes in obesity and the influence of adipokines and inflammatory mediators synthesized by fat cells on psoriatic disease. Advanced glycation end products (AGEs), hyperhomocysteinemia ( $\mathrm{HHcy}$ ) due to vitamin $\mathrm{B}_{12}$ and folic acid deficiency, and a 5,10-methylfolate reductase (MTHFR) mutation are also important in the clinical manifestations of psoriasis. The possibility of assessing metabolic disorders and dysfunction of various organs by changes in the levels of metabolites in the blood and skin of patients with psoriasis is discussed.

Keywords: adipocyte, adipokine, vitamin $B_{12}$, vitamin $D$, inflammation, insulin resistance, metabolomics, oxidative stress, end-glycation products, psoriasis, folic acid.

For citation: Samburskaya OV, Kalinchenko SYu, Batkaeva NV. Biochemical Pathways of Metabolic Disorders in Psoriasis. Juvenis scientia. 2021;7(6):6-16. DOI: 10.32415/jscientia_2021_7_6_6-16. 


\title{
БИОХИМИЧЕСКИЕ ПУТИ РАЗВИТИЯ МЕТАБОЛИЧЕСКИХ НАРУШЕНИЙ ПРИ ПСОРИАЗЕ
}

\author{
О. В. Самбурская (D) ${ }^{1,2}$, С. Ю. Калинченко (1) ${ }^{1,2}$, Н. В. Баткаева ${ }^{1}{ }^{1}$ \\ ${ }^{1}$ Медицинский институт, Российский университет дружбы народов \\ Россия, 117198 г. Москва, ул. Миклухо-Маклая, 6 \\ ${ }^{2}$ Клиника профессора Калинченко \\ Россия, 127015 г. Москва, ул. Бутырская, 4, стр. 2
}

Фамбурская Ольга Викторовна - olga.samburskaya1429@yandex.ru

При псориазе происходит развитие метаболических нарушений: инсулинорезистентности, системного воспаления, атеросклероза, окислительного стресса и ожирения. В статье представлены патологические биохимические пути развития метаболических нарушений, которые обусловлены характерным для псориаза и ожирения цитокиновым профилем, включающим повышенные уровни фактора некроза опухоли альфа (TNF- $\alpha$ ), интерлейина-6 (IL-6) и интерлейкина-8 (IL-8). В развитии инсулинорезистентности играют роль следующие звенья: рецептор инсулина (IRS-1) и субстрат рецептора инсулина (SIR-1), белок-транспортер глюкозы (GLUT-4), также происходит снижение активности фосфатидилинозитол 3-киназного пути (РІЗАКТ) и повышение активности митоген-активирующей протеинкиназы (МAPK). Обсуждаются факторы, влияющие на развитие воспаления: IL-6, С-реактивный белок, тканевой ингибитор активатора плазминогена (PAI-1) моноцитарный хемоатрактант протеин 1 (МСР-1), провоспалительные адипокины; процессы развития сосудистого воспаления, атеросклероза и окислительного стресса. В статье также обсуждаются эндокринные нарушения адипоцитов при ожирении и влияние адипокинов и воспалительных медиаторов, синтезируемых жировыми клетками, на псориатическую болезнь. Рассматривается влияние на клинические проявления псориаза продуктов конечного гликирования (AGEs) и гипергомоцистеинемии (НHсу), обусловленной дефицитом витамина В12 и фолиевой кислоты, а также мутацией 5,10-метилфолат редуктазы (MTHFR). Обсуждается возможность оценки метаболических нарушений и нарушения функции различных органов по изменению уровней метаболитов в крови и коже у пациентов с псориазом.

Ключевые слова: адипоцит, адипокин, витамин B12, витамин D, воспаление, инсулинорезистентность, метаболомика, окислительный стресс, продукты конечного гликирования, псориаз, фолиевая кислота.

Для цитирования: Самбурская О.В., Калинченко С.Ю., Баткаева Н.В. Биохимические пути развития метаболических нарушений при псориазе // Juvenis scientia. 2021. Том 7. № 6 . C. 6-16. DOI: 10.32415/jscientia_2021_7_6_6-16. 
Introduction. The basis of the pathogenesis of psoriasis is interleukin-dependent immunodeficiencies. On the humoral immunity side, the expression of interleukin-4 (IL-4), interleukin-5 (IL-5), interleukin-6 (IL-6), which are responsible for B-lymphocyte activation, increases. The level of interleukin-8 (IL-8) increases, which activates neutrophils, T-lymphocytes. Activated T-lymphocytes produce two different groups of cytokines: T-helpers-1 (Th1)- interleukin-2 (IL-2), tumor necrosis factor alpha (TNF- $\alpha$ ), interferon gamma (IFN- $\gamma$ ) and T-helpers-2 (Th2)-IL-4, IL-5 and interleukin-10 (IL-10). In psoriasis, the cytokines of the Th1 immune response dominate. Levels of IL-10, which suppresses Th1 cytokine production, are decreased. In addition to TNF- $\alpha$ and IFN- $\gamma$, activated $T$ lymphocytes in rashes produce the following cytokines: IL-3, IL-6, and granulocyte-macrophage colony-stimulating factor. Common factors for psoriasis and obesity are: TNF- $\alpha$, IL-6, and IL-8 [1].

Psoriasis is a chronic, relapsing, immune-mediated disease with severe chronic systemic inflammation, which makes psoriatic disease manifest not only by skin and nail lesions but also by joint lesions and systemic manifestations [1, 2]. According to an analytical review of the epidemiology of psoriasis, the incidence in both adults and children has more than doubled over the past thirty years $[3,4]$. And despite the fact that the main etiological factor is genetic predisposition, psoriatic disease is increasingly occurring in people without a hereditary burden. This jump in the incidence of the disease among those with and without heredity is primarily attributed to vitamin D deficiency, which leads to the development of insulin resistance, obesity, decreases skin immunological properties and disrupts the ratio between pro- and anti-inflammatory cytokines [5].

Insulin resistance. One of the main cytokines that plays a key role in the development of insulin resistance in psoriasis and obesity is TNF- $\alpha$.

Insulin resistance is a decrease in the response of insulin-sensitive tissues: adipose tissue, hepatic and transverse striated muscle, to insulin when its concentration is sufficient [6].
It is also known that the same biochemical pathways for the development of insulin resistance, along with TNF- $\alpha$, are stress and increased free fatty acids (uncompleted $\beta$-oxidation of fatty acids in mitochondria leads to the accumulation of excessive amounts of intermediate products of the tricarboxylic acid cycle and the accumulation of long-chain acyl-carnitine CoA [7]) $[8,9,10]$. TNF- $\alpha$ activates inhibitor kappa kinase beta (IKK $\beta$ ) in adipocytes and hepatocytes, which leads to disruption of insulin binding to the receptor as a result of phosphorylation of serine molecules in specific sites of $\beta$-subunits of the insulin receptor type 1 (IRS-1), which reduces its affinity for insulin. And the amount of GLUT-4 transport protein, which is the main intracellular glucose transporter to muscle and fat cells, is reduced [11]. This contributes to insulin resistance, which is accompanied by reduced activation of SIR-1 and FI-3-kinase pathway, which reduces glucose entry into the cell and its use by target organs; reduced activation of two classes of protein kinases ( $B$ and $C$ ) disrupts apoptosis and cell proliferation and leads to disruption of protein synthesis. But if the FI3-kinase pathway is blocked, the MARK pathway continues to function.

Inflammation and atherosclerosis. Produced in psoriasis and insulin resistance IL-6, IL-1B, IL-8 induce a vascular inflammatory response, which leads to the synthesis of C-reactive protein by the liver, which, in turn, is also involved in the progression of insulin resistance and the development of atherosclerosis. Oxidative stress also contributes to the development of atherosclerosis. Oxidized lipoproteins present in the blood are recognized by specific receptors on the surface of macrophages, and macrophages engulf these lipoproteins with the formation of foamy cells that are deposited on the walls of blood vessels as white stripes. And TNF- $\alpha$ also leads to increased production of ITAP-1 (tissue plasminogen activator inhibitor-1), which leads to increased thrombosis.

Inflammatory cytokines, PAI-1, and insulin resistance cause endothelial inflammation that 
increases thrombosis and atherosclerosis. In insulin resistance and obesity there is inactivation of NO due to increased oxidative stress and accumulation of reactive oxygen radicals. The concentration of other endothelium-expanding factors also decreases: prostacyclin, C-type natriuretic peptide, adrenomedulin. The production of vasoconstrictor factors increases: endotellins, thromboxane $\mathrm{A} 2$, prostaglandin $\mathrm{H} 2$, angiotensin 2. The level of intracellular potassium decreases and intracellular calcium and sodium increase, which leads to increased sensitivity of the vascular wall to pressor effects. The combination of the above factors leads to the development of cardiovascular pathology and metabolic syndrome (MS) [11, 12].

Psoriasis contributes to the development of IR, which leads to overweight and obesity, and the increased amount of lipids in the adipocyte activates JNK and IKK $\beta$, the same effect occurs under the influence of proinflammatory cytokines: TNF- $\alpha$ and IL-1 $\beta$, which activate JNK and IKK $\beta / N F-$ kB. Toll-like receptors (Toll-R) located on keratinocytes and Langerhans cells, which bind to bacterial lipid conjugates, participate in the inflammatory response, also join this process. Therefore, in hyperlimidemia, Toll-R binds to endogenous lipids, triggering a cascade of inflammatory responses. And, as mentioned above, psoriasis develops overweight, which in turn leads to activation of reactive oxygen species (oxidants).

Oxidative stress. The presence of oxidative stress in psoriasis patients has been proven in a number of studies: increased malonic dialdehyde activity in the affected skin, erythrocytes and serum and decreased total antioxidant status and activity of antioxidant enzymes: superoxide dismutase and catalase. A positive correlation was found between the activity of psoriatic disease and a decrease in total antioxidant status, and an increase in total oxidative status [13, 14].

Oxidative stress stimulates the expression of TNF- $\alpha$, IL-6, MSR-1 (monocyte chemoattractant, dendritic cells and T-lymphocytes) and decreased production of the protective adipokine, adiponectin (negatively correlates with TNF- $\alpha$ and IL-6, increases NO production and IL-10 secretion, inhibits Toll-R, suppresses IL-17 synthesis). Also, lipid accumulation in the cell disrupts the folding (the process of spatial arrangement of polypeptide chains) of proteins in the endoplasmic reticulum of adipocytes and hepatocytes, which, as well as Toll-R activation and proinflammatory mediator activity, leads to JNK and IKK $\beta / N F-k B$ activation followed by SIR1 phosphorylation. Proinflammatory cytokines also activate JNK NF-kB through a direct linkage mechanism, which leads to an increase in transcription factors, receptors and various proteins, including chemokines (have the ability to attract monocytes and simulate their differentiation into macrophages), adhesive proteins, P- and E-selectins (promote lymphocyte gliding along skin vessels), ICAM-1 (dendritic cell adhesion molecule), VCAM-1 (vascular wall cell adhesion molecule), which supports the circulation of immune cells in the site of inflammation and their adhesion to the corresponding cells, endothelial and dendritic cells with maintenance of the inflammatory process in vessels, with progression of atherosclerosis, and immune cell activation $[12,13,14]$

Adipocytes and psoriasis. Numerous studies conducted in the USA, UK, China, Korea and other countries established that for patients with psoriasis the risk of developing overweight, obesity, arterial hypertension, metabolic syndrome, diabetes mellitus (DM) is twice as high as in the general population. And there is an increased risk of developing psoriasis in adults and children who are overweight, obese, especially abdominal, and MS compared to a population with a normal BMI. Overweight and obesity preceded psoriasis among children with this dermatologic disease in $93 \%$ of cases by two years. Half of the patients who were not overweight or obese before the onset of psoriasis had a dramatic weight gain within the first two years. It has also been found that in overweight, obese, and MS patients, the likelihood of developing psoriasis and its severity and extent increase with weight $[11,15,16$, 
$17,18,19]$. Considering that obesity is a chronic inflammation, it is characterized by the following changes: dyslipidemia, insulin resistance, especially pronounced in abdominal obesity, hyperinsulinemia, leptin resistance (low sensitivity of hypothalamic receptors to leptin, resulting in lack of feeling of satiety after eating (leptin is synthesized by adipocytes), ghrelin resistance (absence or insufficient decrease in blood plasma ghrelin after a meal, resulting in a strong sense of hunger (ghrelin is produced by enteroendocrine cells of the stomach floor)). As a result of insulin resistance there is a disturbance of carbohydrate, fat and protein metabolism, which together with the developing dyslipidemia leads to structural and functional disorders of cell membranes due to changes in their phospholipid composition. Qualitative and quantitative changes in membrane lipids (increased levels of total lipids, cholesterol esters were found in the analysis of the fatty acid spectrum of erythrocyte membranes in obese children and adolescents) leads to disruption of cell membrane elasticity and the entire cytoskeleton is restructured: The configuration of surface active groups in the membrane, the number of channels for various ions changes, the function of integral proteins such as ion pumps, insulin receptors, glucose transporters, and signaling systems is impaired, which leads to structural and functional disorders at the cellular level.

Also, the secretion of cytokines and vasoactive substances is altered in visceral adipose tissue suffering from obesity: The synthesis of proinflammatory mediators - up to $30 \% \mathrm{IL}-$ $6, I L-8, I L-1 \beta$, TNF- $\alpha$ - is increased; production of adipokines with a protective function - adiponectin (negatively correlates with TNF- $\alpha$ and $\mathrm{IL}-6$, increases NO production, regulates $\mathrm{IL}-10$ secretion, regulates toll-receptors, suppresses IL-17 synthesis) and omentin (stimulates vasodilation and tissue revascularization and weakens TNF- $\alpha$-induced adhesion molecule expression, monocyte adhesion) is reduced, and synthesis of pro-inflammatory factors is increased resistin (increases IR), leptin (promotes differentiation of T-lymphocytes into Tx-1, synthesis of IL-6, IL-8,
TNF- $\alpha$ ), chemerin (involved in the pathogenesis of inflammation and development of dyslipidemia), visfatin (stimulates production of proinflammatory factors in monocytes and increases T-lymphocyte activation) retinol-binding protein 4 (involved in the development of IR), fetuin $A$ (induces the synthesis of proinflammatory adipokines), lipocalin-2 (involved in epidermal inflammation, inflammatory bowel disease, positively correlates with IL-1B). Thus, IR leads to the development of fatty hepatitis, obesity, diabetes mellitus, metabolic syndrome (MS), is a trigger of psoriasis development and aggravates the course of psoriatic disease [11, 20, 21, 22].

Advanced glycation end products. An essential role in the development of the inflammatory response in the body is played by advanced glycation end products (AGEs), which are considered as potentially toxic molecules accumulating in the human body and causing the occurrence or progression of complications of diabetes, neurodegenerative, cardiovascular and many other diseases. Endogenous AGEs are formed during aging of the organism, and the source of exogenous advanced glycation end products is cigarette smoke (smoking is the strongest provocateur of psoriatic disease development and aggravates this disease [23]), food rich in fats and proteins, heat-treated (especially, high temperature exposure with formation of a brown crust).

The glycation process is considered as a non-enzymatic modification of proteins, nucleic acids and phospholipids by monosaccharides and reducing oligosaccharides as well as carbonyl compounds - products of their degradation. This process consists of several stages: first, there is a spontaneous non-enzymatic reaction of proteins with sugars (Maillard reaction) due to the interaction between reducing sugars or dicarbonyl products of their decay (glucose, fructose, galactose, mannose, ribose, reactive trioses - intermediates of energy metabolism) and amino groups of lysine, arginine, and sulfur-containing amino acid residues). As a result, labile Schiff bases are rapidly formed, which in turn undergo intramolecular rearrangement 
and form relatively stable Amadori and Hines products (ketosamines, deoxyketoses, or deoxyaldoses). These first two reactions are reversible and the rate of formation of Schiff bases and Amadori products is directly proportional to the monosaccharide concentration, with galactose, fructose and ribose having the highest glycation activity compared to glucose. The next step is the formation of intermediates (glycolaldehyde, glyoxal, glyceraldehyde, methylglyoxal, 3-deoxygluxazone, dicarbonyl) from Schiff bases and Amadori products, which proceeds by three main pathways: The Wolf, Namiki, and Hodge pathways. Stable modified amino acid residues, called advanced glycation end products, or AGEs, are then formed. Only long-lived proteins (collagen, hemoglobins, albumins, crystallins) undergo this process, since it lasts from several weeks to several months, and in the same way amino groups of phospholipids in cell membranes and DNA nucleic acids are modified [24, 25, 26].

There are several ways in which glycation end products affect: already at the stage of glycation intermediates formation, reactive oxygen species - hydrogen peroxide and hydroxyl radical are formed, antioxidant enzymes themselves are glycated, their consumption is increased, which further increases oxidative stress, which causes inflammation and changes in gene expression; loss of function of long-lived glycated protein and cell function disruption due to glycation of intracellular proteins and lipids; there is evidence that glycated metabolites have antigenic properties and induce autoimmune reactions.

Glycation end products interact with the following types of receptors: AGE-R1,2,3 which remove $A G E s$, inhibit increases in reactive oxygen species, and suppress the activation of RAGE-dependent signaling pathways (e.g., suppresses activation of the NF-kB-dependent signaling pathway); macrophage scavenger receptors and RAGE (Receptor For Advanced Glycation End Products), which are expressed in almost all types of CNS cells and are present in monocytes, macrophages, T-lymphocytes, endothelial cells, dendritic cells, fibroblasts, smooth muscle cells, chondrocytes, keratinocytes, melanocytes. AGEs themselves are also capable of enhancing RAGE expression. Ligands for RAGE are also proteins of the S100 family (small calcium-binding proteins characterized as DAMP and having a cytokine-like action), $\beta$-amyloid ( $A \beta 40$ and $A \beta 42$ ), extracellular DNA, phospholipids, and glycosaminoglycans. The interaction of RAGE with one of these ligands activates a number of components of intracellular signaling cascades, including protein kinase $B$, protein kinase $C$, glycogen synthase kinase; GSK3 $\beta$; pSrc- and PI3K-kinase, Rac and Ras GTPases, ERK1/2-, JNK-, MEK-kinases; p38 MAP- and ROCK kinases, early response protein 1Egr-1, transcription factors NF-kB and STAT3. Binding of endogenous and exogenous AGEs to their receptors primarily causes a proinflammatory response mediated by the NF-kB transcription factor responsible for inflammation. Stimulation of RAGE leads to oxidative stress and causes activation of the mitogen-activated kinase cascade (MAPK), which leads to the release and activation of NF-KB, leading to the formation of TNF- $\alpha$ and other proinflammatory cytokines. AGEs lead to inactivation of superoxide dismutase, glutathione peroxidase, and activation of matrix metalloproteinases (MMP). Glycated collagen in skin, vessels, muscles loses its function: the intermolecular cross-linking of collagen fibers becomes rigid and less flexible, which increases its susceptibility to mechanical stresses, but it is highly resistant to the action of MMP, collagen glycation impairs the ability to convert L-arginine to nitric oxide, an essential cofactor in cross-linking collagen fibers, while the charge of the protein on collagen side chains changes, which leads to a disturbance of interaction with surrounding cells and matrix proteins; similar changes occur with other proteins: elastin, fibronectin, and laminin. AGEs inhibit the proliferation of fibroblasts, causing their apoptosis; changes in fibroblast intermediate fibers (vimentin, cytokeratin 10) occur; they reduce the viability of keratinocytes, which express proinflammatory mediators in response to advanced glycation end products $[26,27,28]$. 
A study by Anastasia Papagrigoraki et al. has shown that irrespective of the presence or absence of metabolic disorders, patients with psoriasis have increased levels of AGEs in the skin, which increases inflammation and oxidative stress, worsening the course of the disease. A positive correlation was also found between the severity of psoriasis and the level of AGEs in the skin and blood [29].

Thus, AGEs are a trigger for psoriasis and can exacerbate the course of the disease through increased oxidative stress and inflammation.

Metabolomics. Metabolic changes in psoriasis are not local but systemic, which is confirmed by the high frequency of comorbid pathologies in psoriatic disease: insulin resistance, obesity, diabetes mellitus, arterial hypertension, atherosclerosis, metabolic syndrome. This is why it is so important to evaluate metabolomics, which studies the pathogenesis of psoriasis in terms of inflammation, immunity and inheritance. Determination of metabolite levels reflects changes in gene expression, which reflects the phenotype and functional state of the organism [30].

A number of studies have found that plasma levels of essential amino acids are elevated in psoriasis: threonine, leucine, phenylalanine and tryptophan, increased levels of serine, glycine, histidine, reduced levels of glutamine, cysteine and asparagine (associated with an increased need for synthesis of antioxidant enzymes and methylation processes); also increased levels of lysophosphatidylcholine, free fatty acids (have a cytotoxic effect on pancreatic $\beta$-cells and contribute to endothelial dysfunction, modulate Toll-receptor activity and through binding peroxisome proliferator-activated receptors (PPARs) modulate cytokine and T-helper levels) particularly arachidonic acid and, as a consequence, proinflammatory eicosanoids (leukotriene B4, thromboxane A2, prostaglandin 2, which increase inflammation, provoke atherosclerosis development, synthesis of proinflammatory mediators, increase cyclooxygenase- 1 and 2 levels) elevated levels of uric acid. These changes are associated both with keratinocyte hyperprolifer- ation (increased energy requirement) and with the development of inflammation, endothelial dysfunction, development of subclinical atherosclerosis, impaired liver and kidney function. In psoriatic disease there are increased levels of $\alpha$-ketoglutaric acid ( $\alpha$-ketoglutarate is necessary for collagen synthesis), lactic acid, asparagic acid and glutamic acid, which are also associated with increased energy requirements for protein and cytokine synthesis in conditions of cell hyperproliferation. Increased levels of choline indicate cell hyperproliferation, and increased levels of taurine indicate the presence of inflammation and oxidative stress [30, 31, 32]. The study by Chao Chen et al showed that glutamine, asparagine levels were negatively correlated with the PASI score (Psoriasis Area Severity Index), whereas there was a positive correlation with the levels of alanine, carnosine, ornithine, and phosphoserine, as well as reduced levels of carnitine and its metabolites (essential for fatty acid transport and lipid $\beta$-oxidation) $[33,34]$. In a study by Liis Pohla et al., who compared the metabolites of biopsy specimens from psoriasis-affected and healthy skin, they found a significant difference in 29 components, such as amino acids, biogenic amines, lysophosphatidylcholine, phosphatidylcholine, histamine, carnitine and its metabolites [35], changes similar to blood parameters.

Hyperhomocysteinemia (HHcy). Homocysteine (Hcy) is an intermediate product of methionine metabolism, sulfur-containing amino acid, it is not a structural element of proteins and therefore does not enter the body through food, it is synthesized from methionine. Homocysteine is metabolized in two ways: by the transfer of the sulfate group, which occurs in the presence of vitamin $B_{6}$, or by remethylation, which occurs in the presence of vitamin $B_{12}$ and folic acid. Under physiological conditions the only source of homocysteine in the body is the conversion of methionine. Conversion of excess homocysteine into methionine requires high concentrations of the active form of folic acid (5-methyltetrahydrofolate). The major enzyme responsible for converting folic acid to its active 
form is 5,10-methyltetrahydrofolate reductase (MTHFR). Deficiencies of vitamins $B_{6}, B_{12}$ folic acid and decreased MTHR enzyme activity are the main causes of hyperhomocysteinemia (HHcy) [36].

Studies on the use of $B$ vitamins and folic acid, in particular vitamins $B_{12}, B_{1}, B_{2}, B_{6}$, were conducted in the last century in the $50-60 \mathrm{~s}$, which reported positive treatment results when using these vitamins separately or together [37]. In psoriasis, lack of folic acid and vitamin B12 can be a cause of HHcy, while smoking, alcohol consumption, obesity, atherosclerosis, cardiovascular diseases are associated factors. In vivo and in vitro studies have shown that homocysteine stimulates $T$ cells to secrete the inflammatory mediators IFN- $\gamma$ and IL-2, and promotes their differentiation into Th1, CD4+ into Th17, with increased secretion of IL-17 and inhibits Treg function, which contributes to both psoriasis, atherosclerosis and other cardiovascular diseases. Hcy increases superoxide anion release by neutrophils to the extracellular medium and increases intracellular $\mathrm{H}_{2} \mathrm{O}_{2}$ production by neutrophils. Hcy enhances the activation and phosphorylation of mitogen-activated protein kinases. A positive correlation was found between Hcy and TNF- $\alpha$, IFN- $\gamma$, IL-17 $\alpha$, IL-1 $\beta$, TNF- $\alpha$ and IL-6 and increases the activity of matrix metalloproteinases, increases the activity of the nuclear transcription factor Nf-kB. Given these data, we can assume a positive correlation between homocysteine levels and psoriasis severity [36, 38, 39].

\section{REFERENCES}

1. Molochkov VA, Badokin VV, Albanova VI, et al. Psoriasis and psoriatic arthritis. Moscow: KMK Scientific Publishers Association. Author's Academy, 2007. Р. 300. (in Russ.). [Молочков В.А., Бадокин В.В., Альбанова В.И., и др. Псориаз и псориатический артрит. М.: Товарищество научных изданий КМК. Авторская академия, 2007. 300 с.]

2. Rasin MS. Chronic inflammation, insulin resistance, psoriasis - which have in common? Vestnik Dermatologii i Venerologii. 2016;(5):20-24. (in Russ.). [Расин М.С. Хроническое воспаление, инсулинорезистентность, псориаз - что общего? // Вестник дерматологии и венерологии 2016. № 5. С. 20-24.]

3. Michalek IM, Loring B, John SM. A systematic review of worldwide epidemiology of psoriasis. J Eur Acad Dermatol Venereol. 2017;31(2):205-212. DOI: 10.1111/jdv.13854

4. Burden-Teh E, Thomas KS, Ratib S, et al. The epidemiology of childhood psoriasis: a scoping review. Br J
In a study by Rababeh Abedini et al., homocysteine, vitamin $B_{12}$, folic acid levels were depsoriasis have lower folic acid levels and higher homocysteine levels compared to controls [40]. In a study by SK Çakmak et al., they found a positive correlation between homocysteine levels and the severity of psoriasis [41]. A metaanalysis including 24 studies also confirmed that patients with psoriatic disease have significantly reduced folic acid levels and increased homocysteine levels compared to control groups [42].

Conclusion. Thus, the manifestation of psoriatic disease, even in the presence of genetic predisposition and the development of severe forms of psoriasis, can be under epigenetic control by preventing the development of insulin resistance, obesity, metabolic syndrome, controlling homocysteine, vitamin B12, folic acid, advanced glycation end products, preventing the development of oxidative stress and assessing internal organ functions with metabolomics in mind. Only a holistic approach in the therapy of various diseases, and psoriasis in particular, will help to reduce the risk of manifestation of psoriatic disease, reduce the severity of clinical symptoms, prolong remission and significanty improve patients' quality of life.

Declaration of Conflict of Interest: The authors deare that no competing interests exist.

Funding: The authors declare no funding. termined and it was found that patients with 
Dermatol. 2016;174(6):1242-1257. DOI: 10.1111/bjd.14507

5. Gromova OA, Torshin IYu. Vitamin D: a paradigm shift. Moscow: Geotar-Media, 2018. P. 568. (in Russ.). [Гpoмова О.А., Торшин И.Ю. Витамин D: смена парадигмы. М.: Гэотар-Медиа, 2018. 568 с.]

6. BoytsovSA, Strazhesko ID, Akasheva DU, et al. Insulin Resistance: Good or Bad? Development Mechanisms and the Association with Age-Related Vascular Changes. Cardiovascular Therapy and Prevention. 2013;12(4):9197 (in Russ.). DOI: 10.15829/1728-8800-2013-4-91-97. [Бойцов С.А., Стражеско И.Д., Акашева Д.У., и др. Инсулинорезистентность: благо или зло? Механизмы развития и связь с возраст-ассоциированными изменениями сосудов // Кардиоваскулярная терапия и профилактика. 2013. Т. 12. № 4. С. 91-97.]

7. Bronckers IM, Paller AS, van Geel MJ, et al. Psoriasis in Children and Adolescents: Diagnosis, Management and Comorbidities. Paediatr Drugs. 2015;17(5):373-384. DOI: 10.1007/s40272-015-0137-1

8. Demidova TYu. Etiopthogenic Role of Insulin Resistance in the Development of Metabolic and Vascular Disorders in Type 2 Diabetes Mellitus. Farmateka. 2010;(16):18-24. (in Russ.). [Демидова Т.Ю. Этиопатогенетическая роль инсулинорезистентности в развитии метаболических и сосудистых нарушений при сахарном диабете типа 2 // Фарматека. 2010. № 16(210). С. 18-24.]

9. Taganovich AD, Oletsky El, Kotovich IL. Pathological Biochemistry. Moscow: BINOM Publisher, 2019. 448 pp. (in Russ.). [Таганович А.Д., Олецкий Э.И., Котович И.Л. Патологическая биохимия. М.: Издательство БИНОМ, 2019. 448 с.]

10. Szymczak-Pajor I, Drzewoski J, Śliwińska A. The Molecular Mechanisms by Which Vitamin D Prevents Insulin Resistance and Associated Disorders. Int J Mol Sci. 2020;21(18):6644. DOI: 10.3390/ijms21186644

11. Kong $\mathrm{Y}, \mathrm{Zhang} \mathrm{S}, \mathrm{Wu} \mathrm{R}$, et al. New insights into different adipokines in linking the pathophysiology of obesity and psoriasis. Lipids Health Dis. 2019;18(1):171. DOI: 10.1186/s12944-019-1115-3

12. Ivashkin VT, Drapkina OM, Korneeva ON. Clinical variants of metabolic syndrome. Moscow: Medical Information Agency, 2012. 212 pp. (in Russ.). [Ивашкин В.Т., Драпкина О.М., Корнеева О.Н. Клинические варианты метаболического синдрома. М.: Медицинское информационное агентство, 2012. 212 с.]

13. Pujari VM, Suryakar AN, Ireddy S. Oxidants and antioxidant status in psoriasis patients. Biomedical Research. 2010;21(2):221-223.

14. Zhang Y, Li Z, Ma Y, Mu Z. Association of total oxidant status, total antioxidant status, and malondialdehyde and catalase levels with psoriasis: a systematic review and meta-analysis. Clin Rheumatol. 2019;38(10):26592671. DOI: 10.1007/s10067-019-04676-1

15. Tollefson MM, Van Houten HK, Asante D, et al. Association of Psoriasis With Comorbidity Development in Children With Psoriasis. JAMA Dermatol. 2018;154(3):286-292. DOI: 10.1001/jamadermatol.2017.5417

16. Augustin M, Glaeske $\mathrm{G}$, Radtke MA, et al. Epidemiology and comorbidity of psoriasis in children. Br J Dermatol. 2010;162(3):633-636. DOI: 10.1111/j.1365-2133.2009.09593.x

17. Bronckers IM, Paller AS, van Geel MJ, et al. Psoriasis in Children and Adolescents: Diagnosis, Management and Comorbidities. Paediatr Drugs. 2015;17(5):373-384. DOI: 10.1007/s40272-015-0137-1

18. Becker L, Tom WL, Eshagh $\mathrm{K}$, et al. Excess adiposity preceding pediatric psoriasis. JAMA Dermatol. 2014;150(5):573-574. DOI: 10.1001/jamadermatol.2014.324

19. Han JH, Lee JH, Han KD, et al. Increased risk of psoriasis in subjects with abdominal obesity: A nationwide population-based study. J Dermatol. 2019;46(8):695-701. DOI: 10.1111/1346-8138.14939

20. Potemkin VV. Endocrinology: a guide for physicians. Moscow: Medical Information Agency, 2013. 771 pp. (in Russ.). [Потёмкин В.В. Эндокринология: руководство для врачей. М.: Медицинское информационное агентство, 2013. 771 с.]

21. Dedov II. Diseases of adipose tissue. Moscow: Geotar-Media, 2020. Р. 233. (in Russ.). [Дедов И.И. Болезни жировой ткани. М:. Гэотар-Медиа, 2020. 233 с.]

22. Lykova SA, Spitsina AV, Morzhanaeva MA. Metabolic Syndrome and Psoriasis are as Comorbidity States. Far Eastern Medical Journal. 2017;(1):93-98. (in Russ.). [Лыкова С.А., Спицина А.В., Моржанаева М.А. Ме- 
таболический синдром и псориаз как коморбидные состояния // Дальневосточный медицинский журнал. 2017. № 1. С. 93-98.]

23. Benzian-Olsson N, Dand N, Chaloner C, et al. Association of Clinical and Demographic Factors With the Severity of Palmoplantar Pustulosis. JAMA Dermatol. 2020;156(11):1216-1222. DOI: 10.1001/ jamadermatol.2020.3275

24. Lu C, He JC, Cai W, et al. Advanced glycation endproduct (AGE) receptor 1 is a negative regulator of the inflammatory response to AGE in mesangial cells. Proc Natl Acad Sci U S A. 2004;101(32):11767-11772. DOI: 10.1073/pnas.0401588101

25. Emelyanov VV. Glycation, Antiglycation and Deglycation: Role in Mechanisms of Aging Ang Geroprotective (Literature Review). Advances in Gerontology. 2016;29(3):407-416. (in Russ.). [Емельянов В.В. Гликирование, антигликирование и дегликирование: роль в механизмах старения и геропротекции (обзор литературы) // Успехи геронтологии. 2016. Т. 29. № 3. С. 407-416.]

26. Leonova TS, Vikhnina MV, Grishina TV, et al. Influence of Advanced Glycation end Products on Cellular Processes. International Research Journal. 2018;(12-1):185-194. DOI: 10.23670/IRJ.2018.78.12.034. (in Russ.). [Леонова Т.С., Вихнина М.В., Гришина Т.В, и др. Влияние конечных продуктов глубокого гликирования на клеточные процессы // Международный научно-исследовательский журнал. 2018. № 121(78). C. 185-194.]

27. Lee EJ, Kim JY, Oh SH. Advanced glycation end products (AGEs) promote melanogenesis through receptor for AGEs. Sci Rep. 2016;6:27848. DOI: 10.1038/srep27848

28. Lykova SG, Svechnikova EV, Morzhanaeva MA. Advanced Glycation end Products as Biomarkers of Aging. Bulletin of the Russian Academy of Natural Sciences. 2018;18(2):71-77. (in Russ.). [Лыкова С.Г., Свечникова Е.В., Моржанаева М.А. Конечные продукты гликирования как биомаркеры старения // Вестник Российской академии естественных наук. 2018. Т. 18. № 2. С. 71-77.]

29. Papagrigoraki A, Maurelli M, Del Giglio M, et al. Advanced Glycation End Products in the Pathogenesis of Psoriasis. Int J Mol Sci. 2017;18(11):2471. DOI: 10.3390/ijms18112471

30. Lian N, Shi LQ, Hao ZM, Chen M. Research progress and perspective in metabolism and metabolomics of psoriasis. Chin Med J (Engl). 2020;133(24):2976-2986. DOI: 10.1097/CM9.0000000000001242

31. Li SS, Liu Y, Li H, et al. Identification of psoriasis vulgaris biomarkers in human plasma by non-targeted metabolomics based on UPLC-Q-TOF/MS. Eur Rev Med Pharmacol Sci. 2019;23(9):3940-3950. DOI: 10.26355/eurrev_201905_17823

32. Wójcik P, Biernacki M, Wroński A, et al. Altered Lipid Metabolism in Blood Mononuclear Cells of Psoriatic Patients Indicates Differential Changes in Psoriasis Vulgaris and Psoriatic Arthritis. Int J Mol Sci. 2019;20(17):4249. DOI: 10.3390/ijms20174249

33. Chen C, Hou G, Zeng C, et al. Metabolomic profiling reveals amino acid and carnitine alterations as metabolic signatures in psoriasis. Theranostics. 2021;11(2):754-767. DOI: 10.7150/thno.51154

34. Ottas A, Fishman D, Okas TL, et al. The metabolic analysis of psoriasis identifies the associated metabolites while providing computational models for the monitoring of the disease. Arch Dermatol Res. 2017;309(7):519528. DOI: 10.1007/s00403-017-1760-1

35. Pohla L, Ottas A, Kaldvee B, et al. Hyperproliferation is the main driver of metabolomic changes in psoriasis lesional skin. Sci Rep. 2020;10(1):3081. DOI: 10.1038/s41598-020-59996-z

36. Lin X, Meng X, Song Z. Homocysteine and psoriasis. Biosci Rep. 2019;39(11):BSR20190867. DOI: 10.1042/ BSR20190867

37. Mashkileyson LN. Private Dermatology. Moscow: "Medicina" Publishing House, 1965. 522 pp. (in Russ.). [Машкилейсон Л.Н. Частная дерматология. М.: Издательство «Медицина», 1965. 522 с.]

38. Wang WM, Jin HZ. Homocysteine: A Potential Common Route for Cardiovascular Risk and DNA Methylation in Psoriasis. Chin Med J (Engl). 2017;130(16):1980-1986. DOI: 10.4103/0366-6999.211895 
39. Beranek M, Malkova A, Fiala Z, et al. Goeckerman Therapy of Psoriasis: Genotoxicity, Dietary Micronutrients, Homocysteine, and MTHFR Gene Polymorphisms. Int J Mol Sci. 2019;20(8):1908. DOI: 10.3390/ijms20081908

40. Abedini R, Goodarzi A, Saeidi V, et al. Serum homocysteine level, vitamin B12 levels, and erythrocyte folate in psoriasis: A case-control study. Int J Womens Dermatol. 2019;5(3):171-174. DOI: 10.1016/j.ijwd.2018.12.004

41. Cakmak SK, Gül U, Kiliç C, et al. Homocysteine, vitamin B12 and folic acid levels in psoriasis patients. J Eur Acad Dermatol Venereol. 2009;23(3):300-303. DOI: 10.1111/j.1468-3083.2008.03024.x

42. Tsai TY, Yen H, Huang YC. Serum homocysteine, folate and vitamin B12 levels in patients with psoriasis: a systematic review and meta-analysis. Br J Dermatol. 2019;180(2):382-389. DOI: 10.1111/bjd.17034

Поступила в редакцию: 31.10 .2021

После доработки: 17.12 .2021 